\title{
A newspaper for immigrants. Spanish-Italian interference in Expreso Latino
}

\author{
Ma Elena Gómez Sánchez* (Madrid)
}

\begin{abstract}
This contribution studies Spanish-Italian interference appearing in Expreso Latino, a newspaper for Latino immigrants broadly distributed in Italy, which offers interesting examples of two closely related languages in contact. The data constitute a field for the study of more general aspects related to intercultural communication.
\end{abstract}

\section{Introduction. Latin American migration in Italy and media}

In the past ten years, both Spain and Italy have been two of the European countries in which the migrant population has steadily increased. In 2009, figures showed 5,262,000 immigrants in Spain and 4,330,000 in Italy, meaning that this population has grown by a factor of 5 and 3, respectively, over the past ten years. When focusing specifically on the immigrant population coming from Latin America, this group in Italy represents $18 \%$ of the total of the migrant population, with the number slightly eclipsing 300,000 people. The most important countries of origin are represented in the following table:

\begin{tabular}{|l|l|l|l|}
\hline Country & Total & \% & \% of women \\
\hline Ecuador & 80,070 & 2.1 & 59.4 \\
\hline Peru & 77,629 & 2.0 & 60.2 \\
\hline $\begin{array}{l}\text { Dominican } \\
\text { Rep. }\end{array}$ & 20,583 & 0.5 & 65.9 \\
\hline Colombia & 18,615 & 0.5 & 64.1 \\
\hline Cuba & 15,883 & 0.4 & 76.4 \\
\hline Argentina & 11,842 & 0.3 & 55.6 \\
\hline Bolivia & 6,796 & 0.2 & 63.2 \\
\hline El Salvador & 6,552 & 0.2 & 63.3 \\
\hline Venezuela & 5,339 & 0.1 & 67.6 \\
\hline Chile & 3,641 & 0.1 & 57.4 \\
\hline
\end{tabular}

Table 1: Number of Latin American immigrants in Italy by country of origin (see Caritas-Migrantes 2009).

Most of the immigrant population settles in the areas surrounding the largest cities in Italy, due to both better job opportunities and better networks of services to residents. After an initial settlement phase in which the immigrant population needs to take care of basic aspects related to their new situation in a foreign country, a second phase begins, in which more everyday aspects start to slowly but steadily become relevant. Among these daily aspects, the need (and the will) to be informed appears. To do so, migrants may turn to the regular media of their new country, but they may also turn to the media of their countries of origin

\footnotetext{
* M Elena Gómez Sánchez is Professor of Journalistic Writing at Universidad Europea de Madrid.
} 
(especially with the help of the Internet: digital press, radio and TV). As a third option, they can take advantage of the ethnic media (cf. Shiramizu 2000) or multicultural media (cf. Maneri/Meli: 2007). As Gómez Escalonilla and Santín (2009: 2) state

son los llamados medios de la diáspora [diasporic media] o también medios de minorías étnicas [minority media], medios que juegan cierto papel en el proceso migratorio y en la formación de identidades culturales o colectivas, como han abordado algunas investigaciones que analizan el papel de estos medios en los procesos de integración.

These media are normally - although sometimes not exclusively -, organized by migrants and oriented toward migrants; they can be addressed to a specific nationality or, in a wider sense, to migrants that share some circumstances (such as language), but not necessarily their country of origin. According once again to Gómez Escalonilla (2008), these media allow migrants to keep some links with their country of origin (which could be especially important for the second generation migrants), while at the same time help migrants to establish links with the culture of their new place of residence. These media can also help to put different groups of migrants in contact, who could share some common interests. This is the context in which we should examine the newspaper Expreso Latino.

\section{Expreso Latino}

Expreso Latino belongs to the publishing group Stranieri in Italia, which is the most important publishing house in Italy oriented toward immigrants. It started in 2000 with a website (www.stranieriinitalia.it/) and then expanded to the printed media sector. At the moment in which this research was carried out, it printed around 250,000 copies in total, including twenty different ethnic papers in fifteen different languages ranging from Spanish or Romanian to Ukrainian or Hindi. Most of these papers can also be found as PDFs on their particular sites, which are linked to the general homepage of Stranieri in Italia.

Expreso Latino started in 1998 as an initiative of an Ecuadorian journalist, Rolando Ortega, and six years later became part of Stranieri in Italia. In the moment of carrying out this research, it printed 25,000 copies monthly to be distributed in Italy, and another 15,000 to be distributed in the United Kingdom. The paper's editor at the time was Sergio Mora, an Argentinean journalist. A group of Latin American journalists living and working in Italy oversee the national news, while Internet and local papers from Latin America are the sources for the news regarding the countries of origin of the immigrants they address. Their estimated number of readers per month at the time of this research was 200,000, while their webpage receives far fewer visits: around 3,000 for the same period (cf. Mapelli 2010, 178). In the analysis that will follow, we have considered six issues from 2010, from January to June.

Expreso Latino is a news-paper: it has no editorial or op-ed pages. The 24 pages forming every monthly issue are devoted to information, divided into different sections. First of all, the front page normally focuses on an important issue related to the "job world" or administrative aspects relevant to the situation of Latin-Americans in Italy. The lower part of the first page is devoted to advertisements: Western Union and Vodafone are the two enterprises that advertise in this space; sometimes Stranieri in Italia itself appears in place of Vodafone. After that, several sections follow: "Actualidad Inmigración", "Latinoamérica Hoy", "Latinoamericanos en Italia", "Guía a la Ley", "Deporte" y "Entretenimiento" (or "Actualidad Inmigración", "Italia-Latinoamérica", "Internacional", "Latinoamericanos en Italia", "Guía a la Ley", "Deporte", "Entretenimiento").

"Actualidad Inmigración" is devoted to those pieces of information that are more relevant to immigrants and their status in Italy (ranging from laws related to work situations or conditions to other basic know-how related to schools, services, etc.) while "Guía a la Ley" focuses on the specific development of laws or other legislation related to immigration, sometimes in the 
(pedagogical) form of question-answer. "Latinoamericanos en Italia" and "ItaliaLatinoamerica" focus on different aspects and activities of the Latin American communities in Italy, and these sections try to favor mutual knowledge, also with the hosting society. "Latinoamerica hoy" and "Internacional" offer news about the readers' countries of origin. Whole pages, and also sections of pages, are also devoted to advertisements.

\section{The language in Expreso Latino: Spanish-Italian interferences}

The first aspect that we should consider here is deeply related to the legal or administrative terms representing concepts that immigrants quickly need to learn for the success of their new life in Italy. These terms are often related to the administrative process that they need to go through during their first months in the country, but are also related to other aspects, such as how to find job opportunities or schools for their children. We find several attestations of these terms appear in the pages of Expreso Latino.

\subsection{Both the Italian term and its translation in Spanish appear}

(1) En 23 mil casos corrió todo bien: el empleador ha firmado el contrato de estadía junto al trabajador, que pudo pedir por lo tanto el permiso de estadía (permesso di soggiorno). (January, p. 2)

(2) Nadie puede denunciar a un inmigrante sin permiso de estadía (permesso di soggiorno) que entre en un hospital, en emergencias (pronto soccorso) o en cualquier estructura del Servicio Sanitario Nacional (SSN). (January, p. 3)

(3) Los 'permesso [sic] di soggiorno' (permisos de estadía) que esperan una decisión de las oficinas de la Prefectura en Milán: 30 mil de permisos de estadía que aún quedan del 2008, más 44 mil de la regularización o 'sanatoria' de trabajadores del hogar (colf e badanti) realizada el mes de septiembre pasado. (February, p. 2)

(4) Como cada año fueron aumentados los subsidios o cheque de maternidad -en Italia llamado 'assegno'- que la Comuna entrega. (March, p. 17)

(5) Todas las trabajadores [sic] domésticas tienen derecho a la pausa de maternidad (congedo di maternita'), y a recibir el sueldo. (March, p. 19)

(6) Una cena afuera con los amigos puede costar caro, por ejemplo la suspensión de la licencia de manejar (patente), por haber bebido solamente tres cervezas o más de un vaso de vino. (January, p. 19)

(7) El código de manejo (códice della strada) en el artículo 186 establece que: [...] (January, p. 19)

(8) El acuerdo de integración incluirá el conocimiento del idioma italiano y de la Constitución y un sistema de puntaje, como sucede con la licencia de conducir (patente a punti) (March, p. 2)

(9) Lo que parecía imposible ahora se está concretizando, gracias a los trabajadores que fueron contratados en las diversas "questura" (centrales de policía) y "sportello unico" (ventanillas que realizan los trámites) (May, p. 6)

(10) "Tengo un permiso para trabajo subordinado (permesso di soggiorno per lavoro subordinato), estoy como trabajadora doméstica" (May, p. 17)

Less often, what appears is not a translation, but an explanation of the term, as in the next example:

(11) El 'assegno sociale' es la cantidad mínima de dinero que se considera necesaria para vivir. (March, p. 19) 


\subsection{References in Italian to legal texts or administrative institutions, not translated}

Quite opposite to what has just been explained, when it comes to the denomination of laws or decrees, or the names of official institutions, the references stay in Italian and are not translated:

(12) De acuerdo con el "Testo único sull'immigrazione", el número de visas muestra la disponibilidad de lugares reservados a los estudiantes residentes en el exterior, ya que quienes se encuentran el Italia pueden inscribirse en paridad de condiciones respecto a los italianos. (January, p. 2)

(13) Lo indicó el Ministerio del Interior con una circular que explica como la "Legge sicurezza" que introdujo el delito de clandestinidad, no permite denunciar al clandestino o irregular que vaya a una estructura sanitaria. (January, p. 3)

(14) Una pequeña modificación al texto único sobre la inmigración, aprobada el $11 \mathrm{de}$ febrero con la conversión en ley del decreto "mille-proroghe", le permitirá al gobierno conceder también este año nuevas entradas en Italia por motivo de trabajo. (March, p. 3)

(15) Una población extranjera con necesidades de salud similares a la italiana, pero que le cuesta menos al Servicio sanitario nacional, Lo [sic] indica la "Relazione sullo stato sanitario del Paese" presentada en diciembre por el "Ministero del Lavoro, della Salute e delle Politiche Sociali" referente al período 2007-2008. (January, p. 3)

(16) El estudio del 'Centro de di [sic] Ricerca educativa e sociale de la Universitá di RomaTre' fue realizado por encargo del 'Organismo nazionale di coordinamento per le politiche di integrazione sociale degli stranieri', y presentado en el 'Parlamentino del Cnel (Consiglio Nazionale dell'Economia e del Lavoro) (January, p. 4)

Again, exceptions to this general situation are very rare, but they do still occur:

(17) Lo indica el informe "Gli alunni stranieri nel sistema scolastico italiano 20082009", publicado por el Ministerio de Educación de Italia. (May, p. 4)

\subsection{Borrowings}

We have also found some examples of words that stay in Italian in the middle of a text written in Spanish, but they appear between single quotation marks, indicating that one is faced with an Italian borrowing. It is interesting that these cases normally correspond to terms which belong to everyday situations:

(18) Javier es el retrato de un inmigrante latinoamericano medio. Peruano, trabaja en un parque de diversiones de Roma con contrato 'a tempo indeterminato' (February, p. 4)

(19) Apenas llegó a Génova, entró en la 'elementari', en la escuela media tuvo la primera 'fidanzatina' y hoy su novia es de Etiopía. (March, p. 11)

(20) Anthony, es un obrero metalúrgico que está en Italia desde hace ocho años y decidió llamarlo así a su hijo porque "gracias a Berlusconi obtuve mi 'permesso di soggiorno'". (May, p. 6)

More unusual is to find borrowings in headlines, though one can still find examples, as in the following: 
(21) Sciopero de inmigrantes virtual pero impactante (April, p. 5)

(22) Bastará "soggiorno" para viajar en área Schengen (May, p. 1)

(23) Está en Italia por "ricongiungimento" (May, p. 6)

(24) "Soggiorno" a puntaje para los futuros inmigrantes (June, p. 1)

\subsection{Hybridization of Spanish and Italian languages: calques}

There are cases in which a word or a grammatical construction belonging to the Italian language appears as if it would belong to Spanish. Normally, the word also exists in Spanish, but with a completely different meaning from the Italian meaning intended by the author (that meaning would not be appropriate in that context in Spanish). Some examples follow (bold typeface is ours):

(25) Benedicto XVI concluyó con el augurio de "que, en el ámbito de los organismos y comunidades eclesiales, el perdón ofrecido y recibido en nombre y por amor de la Santísima Trinidad, que adoramos en nuestros corazones, ponga fin al sufrimiento de la amada Iglesia que peregrina en las tierras de la Santa Cruz". (January, p. 6)

In this context, the word augurio would mean 'wish' in Italian, while in Spanish it would correspond to 'prediction'.

(26) La OnLus Apurimac, fuertemente empeñada en proyectos de solidaridad en Perú, este año participa además a la iniciativa 'Mettiamo a fuoco la solidarietà' organizada por la Wind, y destinada a ayudar a la infancia en dificultad. (January, p. 10)

(27) Al firmarlo la persona se empeña a conseguir en dos años un conocimiento medio (nivel A2) de italiano y un conocimiento 'suficiente' de los 'principios fundamentales de la Constitución' [...]. (June p. 2)

In these contexts, the verb empeñarse has taken the place of assumere il impegno, meaning 'to be committed' (or 'to commit yourself to do something') in Italian, while in Spanish the meaning is more related to a 'to insist upon' something. Even if they semantically share some aspects, the sense and usage differ between the two languages.

(28) Destinado a hacer conocer en Italia la culinaria del país andino, [...].En los históricos salones contiguos a la iglesia ubicada en Piazza del Popolo, fue el concurso de culinaria [...] (January, p. 12)

Culinaria would be the common Italian word for the Spanish gastronomia, or English gastronomy. In Spanish, culinaria would be used as an adjective ("muestra culinaria", for example), but not as a noun.

(29) En la Capital se abrieron las inscripciones a las escuelas de la infancia comunales (February, p. 4)

(30) La Comuna dirigida por Anna Maria Cancellieri decidió aplicar la "Legge sicurezza", en vigor desde agosto pasado (May, p. 4)

The word Comuna and its derivates (such as comunales) could be translated as Ayuntamiento, municipio or municipales, depending on the context. In DRAE (Diccionario de la Real Academia Española), the word comuna means, in its first sense, 'conjunto de personas que viven en comunidad económica, a veces sexual, al margen de la sociedad organizada', even if 
in its third sense the Spanish Dictionary includes the American use of comuna as 'municipio', 'conjunto de los habitantes de un mismo término'.

(31) En la escuela de la infancia (nido, asilo, jardín de infantes) el porcentaje llega al 3,5 por ciento. (May, p. 4)

The word asilo in Italian means 'kindergarden', and in this example is intended as synonym of nido or jardin de infantes, but in Spanish it means completely the opposite, 'residence for elder people'.

(32) El juez puede disponer sanción accesoria, un trabajo de pública utilidad en la provincia de residencia de uno a seis meses y si el culpable se niega puede sufrir un año de cárcel. (January, p. 19)

The word accesoria means 'complementary' in Italian, but its meaning in Spanish is closer to 'superficial'.

(33) Entre ellos un grupo de nordafricanos hizo destrozos y dañó negocios prevalentemente de peruanos. (March, p. 3)

Negocios would be an adaptation from the Italian negozi, meaning 'shops' (or 'tiendas' or 'comercios' in Spanish). The meaning of negocios would be more related to the concept of 'business'.

(34) "Oficiar una misa en Santo Stefano - recalcó el padre Quadri - no sólo me llena de emoción, sino me siento muy bien porque soy muy aficionado a los latinoamericanos. Ellos son muy cariñosos conmigo y yo también los quiero mucho y no podría vivir sin mis latinos". (May, p. 8)

Essere affezionato, in Italian, means 'to be fond of', or even 'be close to', and it can be applied to people. But, in Spanish, ser aficionado $a$ is only possible when applied to hobbies or material things, and not to people.

(35) Según lo establecido por la Circular INPS n. 101 del 10 de agosto 2009, una vez definido el procedimiento de emersión [...] (January, p. 19)

Emmersione would be the Italian term for 'regulation'. The term emersion is not used with this meaning in Spanish, but only as the physical opposite movement to inmersión. It is also worth noticing that in another issue of the newspaper, published two months later, the word that appears is regularización:

(36) Para los que se quedaron afuera de la 'regularización' (March, p. 1)

We find a different situation when we have words that are partial adaptations of Italian words or grammatical constructions; as a result, we have a new word or construction which is neither Italian nor Spanish:

(37) Aprender una lección: la emarginación engendra violencia (February, p. 1)

In this case, emarginación is a calque on Italian emarginazione, while in Spanish the correct word would be marginación.

(38) Marisol Toral, durante su apelo en Turín (March, p. 15)

(39) Corte UE acepta el apelo (April, p. 14)

Apelo is an adaptation from the Italian appello, but it would be petición (because apelación has a very restricted meaning, related to the legal world) in Spanish, 'claim', in English. 
(40) Sobre la xenofobia, etimológicamente miedo del extranjero, los italianos a veces lo son, pero en general suelen ser abiertos. Se dice incluso que son estereófilos. (February, p. 2)

In this case, there is an adaptation of the noun estero ('foreign' in Italian), together with the Greek term -filo; but the result is neither Italian nor Spanish.

(41) Pero cuando saben que quien les da algún fastidio les beneficiará en algo, entonces las cosas cambian. Sucede con los turistas hacia los cuales se les soporta si ponen los pies en la Fontana de alguna plaza, porque al final de cuentas la fontana es pública y ellos traen dinero. Si quienes le dan algún fastidio son personas que consideran no le darán una ventaja concreta, entonces la actitud cambia. (February, p. 2)

The expression dar fastidio, very common in Italian, would be translated in Spanish as the verb fastidiar or molestar ('bothering' in English), but it would not be used as it appears here. It is also worth noticing the use of the word fontana instead of fuente.

(42) Para tomar cita llamar al XXXX o escribir una e-mail a XXX (advertisment, January, p. 2)

E-mail is feminine in Italian, but masculine in Spanish.

(43) Lo pidió Benedicto XVI el domingo 17 de enero, en la Jornada Mundial del Migrante y el Refugiado, durante el rezo del Ángelus en Plaza San Pedro. (February, p. 4)

The absence of article la before Plaza San Pedro would be typical in Italian (Piazza San Pietro), but not in Spanish.

(44) Naturalmente la ventanilla a la cual los empleadores y badantes deberán presentarse será indicado (March, p. 2)

The construction será indicado is a loan translation from Italian, while in Spanish it would be more natural to say se indicará.

(45) Desde hace 10 años se ocupa específicamente en temas sobre inmigración e integración y desarrolla proyectos de cooperación internacional a favor de Latinoamerica y realiza iniciativas relacionados a los extranjeros residentes en Italia. En el año 2008 viene seleccionado y participa en el curso introductivo para la preparación de expertos en migración (April, p. 8)

The construction viene seleccionado is, again, a loan translation from Italian, while in Spanish it would be more natural to say fue seleccionado, with the verb ser instead of venir.

(46) "Soggiorno" a puntaje para los futuros inmigrantes (June, p. 1)

The preposition $a$ is Italian, while in Spanish it would be con or de. In that same issue of the newspaper, on the next page, the headline of one of the stories is half-Italian, half-Spanish:

(47) "Soggiorno a punti" cambia el sistema (June, p. 2)

(48) Los inmigrantes en media ganan unos 1000 euros por mes, trabajan marido y mujer y sus hijos 'tifan' en fútbol 'la nazionale italiana' (February, p. 4)

The verb tifar is Italian ('support a team', normally related to football), but the conjugation of the third person plural does not correspond to Italian (right conjugation would be tifano), but to a supposed (and incorrect) form of Spanish. 


\section{Conclusions}

Ethnic media represent an interesting field of study for both social and linguistics reasons. On the one hand, they represent a point of contact between the social reality that immigrants face when they arrive in a new country and the cultural background they bring along, so the ties with their countries of origin are maintained and supported by these newspapers. On the other hand, the mixing of two closely related languages - Spanish and Italian in the case of Expreso Latino - offers many examples of how the new concepts that immigrants have to learn are presented and translated (maybe even achieving a pedagogical result), while others are simply included in Italian (those which may constitute the legal or administrative background of the terms which are really of basic need for the immigrants, but that do not by themselves have such a strong importance for the reader). Finally, a good number of examples also show the interferences that occur between these two closely related languages when the one language is written in the country of the other: borrowings and calques appear quite often on the pages of Expreso Latino, showing the influence of the Italian language on Spanish.

\section{References}

Caritas-Migrantes (eds.) (2009): Immigrazione. Dossier statistico 2009. XIX Rapporto sull'immigrazione.

http://www.caritas.it/materiali/Pubblicazioni/libri_2009/dossier_immigrazione2009/sc heda.pdf, accessed January 13, 2014.

Gómez-Escalonilla, Gloria (2008): Voces de la inmigración. Medios latinos en Madrid. Madrid: Universitas.

Gómez-Escalonilla, Gloria/Santín, Marina (2009): "Voces latinas. El periodismo de la inmigración". Actas del I Congreso Internacional Latina de Comunicación Social 2009: 1-11. http://www.revistalatinacs.org/09/Sociedad/actas/79gloria.pdf, accessed January 18, 2014.

Maneri, Marcello/Meli, Anna (eds.) (2007): Un diverso parlare. Il fenomeno dei media multiculturali in Italia. Roma: Carocci.

Mapelli, Giovanna (2010): "Informazione e multiculturalità. Il caso di Expreso Latino". In: Calvi, Maria Vittoria/Mapelli, Giovanna/Bonomi, Milin (eds.): Lingua, identità $e$ immigrazione. Prospettive interdisciplinari. Milano, Franco Angeli: 173-190.

Real Academia Española (2001): Diccionario de la lengua española. 22. ed. Madrid: Espasa Calpe.

Shiramizu, Shigehiko (2000): "Global migration, ethnic media and ethnic identity". Asian and Pacific Migration Journal, 9, 3: 273-285. 